\title{
SOLID WASTE AND CONTAMINATING AGENTS ON THE NORTHERN COASTAL BEACHES OF PERNAMBUCO
}

\author{
Deise Mendes de Araújo CUNHA ${ }^{1}$; \\ Aislan Galdino da CUNHA ${ }^{2}$; \\ Maurício Alves da MOTTA-SOBRINHO ${ }^{1}$; \\ Leandro DANIELSKI ${ }^{1}$; \\ Silvana Carvalho de Souza CALADO ${ }^{1}$
}

Recebido em: 14/01/2014

Aceito em: $20 / 10 / 2014$

\section{ABSTRACT}

The study aims to evaluate the qualiquantitative profile of solid waste on three beaches with distinct characteristics of use located on the island of Itamaracá, Brazil. In each beach, area was randomly determined with three samples taken from each. After the locations were chosen, first, they were cleaned up and all waste was collected. This waste was quantified, weighed, and classified, according to the type of material and probable use. The total number of collected items was 1320: $1206(91.4 \%)$ plastic and $114(8.6 \%)$ other types of material. This is waste related to beach activities, mostly recreational, representing $40 \%$ of the waste in the samples, demonstrating that the amount of solid waste is directly linked to the flow of users. In other words, the higher the number of users, the greater is the improper disposal of waste. The results demonstrate the need for more environmental education programs.

Key Word: Pollutant Source, Environmental Characterization and Marine Pollution.

\section{RESUMO}

O estudo tem como objetivo avaliar o perfil quali-quantitativa dos resíduos sólidos em três praias com características distintas de uso localizado na ilha de Itamaracá, Brasil. Em cada área de praia foi determinada aleatoriamente com três amostras colhidas em cada. Depois que os locais foram escolhidos, primeiro eles foram limpos e todos os resíduos foram recolhidos. Este resíduo foi quantificado, pesados e classificados de acordo com o tipo de material e à utilização provável. O número total de itens coletados foi 1320: 1.206
$(91,4 \%)$ de plástico e $114(8,6 \%)$ outros tipos de material. Esse resíduo foi relacionado com atividades na praia, principalmente de lazer, o que representa $40 \%$ dos resíduos nas amostras, o que demonstra que a quantidade de resíduos sólidos está diretamente ligado ao fluxo de usuários. Em outras palavras, quanto maior for o número de utilizadores, o maior é a eliminação inadequada de resíduos. Os resultados demonstram a necessidade de programas de educação ambiental mais.

Palavras chave: Fonte Poluidora, Caracterização Ambiental e Poluição Marinha.

\section{INTRODUCTION}

Solid waste from human activities, in recent decades, are among the greatest environmental problems and have only begun to be taken seriously by society (DEMAJOROVIC 1996). The inappropriate disposal of these wastes contributes to increased pollution in the terrestrial and aquatic environments of the entire planet; the oceans, however, which cover two-thirds of the earth's surface, are the most affected (ARAÚJO, COSTA 2003).

The oceans are suffering from the great input of solid waste, which harms marine biota. This is happening because many people still believe, erroneously, that these environments have a capacity to support and assimilate waste (ARAÚJO, COSTA 2003).

According to United Nations Convention on the Law of the Sea, pollution of the marine environment is defined thusly: 'pollution of the marine environment' means the introduction by man, directly or indirectly, of substances or energy into the marine environment, including

\footnotetext{
${ }^{1}$ Universidade Federal de Pernambuco, Departamento de Engenharia Química; ${ }^{2}$ Universidade Federal do Pará, Departamento de Zoologia; mendes_deise@hotmail.com, aislangc@hotmail.com, mauricio.motta@pq.cnpq.br, leandro.danielski@ufpe.br, silcalado@yahoo.com.br.
} 
Cunha, D. M. de A.; Cunha, A. G. da; Mota-Sobrinho, M. A. da; Danielski, L.; Calado, S. de C. Solid waste and contaminating agents on the northern coastal beaches of Pernambuco.

estuaries. which results or is likely to result in such deleterious effects as harm to living resources and marine life, hazards to human health, hindrance to marine activities, including fishing and other legitimate uses of the sea, impairment of quality for use of sea water and reduction of amenities' (AMLG 2013).

Pollution of beaches, by solid waste, is damaging to the aesthetic and the local tourism potential, as waste adversely affects the quality of waters, causing health risks to the users and causing harmful effects to marine biota (SANTOS et al. 2004; DIAS FILHO et al. 2011). The control of marine pollution, in coastal zones, is linked to environmental management, because the society's participation is very important. The UN Montego Bay convention placed responsibility for this on all, including civil society (subjective responsibility) (MARTINS 2008).

The issue of solid waste on the beaches has its origins linked to anthropogenic activities such as: tourism, recreation, fishery and things discarded from boats. The length of how long this waste remains in the beach areas can be evidenced from the zones in which it can be found: The Sublittoral and Intertidal zones have recent waste deposits (approximately one day); and the Supralittoral zone, waste that has been there for longer than a day (OLIVEIRA TESSLER, TURRA 2011).

Based on CARVALHO-SOUZA \& TINÔCO (2011) the solid waste in coastal areas can be categorized into: Waste left by bathers - typically consists of food packaging, remains of clothing and remains of recreational materials. Terrestrial waste - material disposed from estuaries and beaches in industrial and urban areas. Maritime waste - from the fishing industry and navigation along the continental shelf, including waste from oil prospecting. Oceanic waste - transported from sources beyond the continental shelf.

Solid waste can be classified according to the source material (plastic, wood, metal, glass and paper) (CARVALHO-SOUZA, TINÔCO 2011) and source (recreation, fishing, personal habits, among others) (SANTANA-NETO et al. 2011). In recent studies, plastic is the raw material that dominates the composition of solid waste, representing about 50\% (ARAÚJO, COSTA 2003; MASCARENHAS et al. 2008; NEVES et al. 2011; BRUNO, SANTOS 2011; DIAS-FILHO et al. 2011).

Wastes derived from petroleum (plastic, rubber, nylon, polystyrene) are the materials that predominate in marine environment. Of the 10 million tons of solid waste disposed in the sea per year, $10 \%$ of this total is made up of plastic. These derivatives have become a major concern in terms of pollution at sea, because plastics float, thus dispersing widely, they are insoluble, and degrade very slowly (SANTOS 2006).

Contamination by solid waste on the beaches of Itamaracá Island, on the northern coast of Pernambuco, mainly occurs during periods of peak tourist season. This waste is located along the high line tide, because the discarded trash in the sand, if not collected immediately, is washed away along around the coastline, contaminating and re-contaminating the beaches on its way (ANTIA 1993). It is for this reason that a preliminary characterization of the solid waste found on beaches serves as a tool for determining the potential risks in a place. These characteristics include size (RIBIC et al. 1992), the composition of the waste (DIXON, DIXON 1983), and polluting source (CLAEREBOUDT 2004; REES, POND 1995). From this information, program measures can be elaborated favoring a new approach on this issue and measures can be sought, which may stop or minimize these problems.

Considering this, the present study has as its characterizing goals to classify and relate the solid waste to its respective human activities, on the beaches of the island of Itamaracá, located on the northern coastal region of the state of Pernambuco in the Northeast of Brazil.

\section{STUDY AREA/ÁREA ESTUDADA}

The coast of Pernambuco State extends for $187 \mathrm{~km}$, spanning fifteen municipalities, among these, the Island of Itamaracá which is located on the northern coast of Pernambuco (Figure 1) between the parallel $07^{\circ} 41^{\prime}$ and $07^{\circ} 49^{\prime}$ latitude South; $034^{\circ} 49^{\prime}$ and $034^{\circ} 54^{\prime}$ longitude west, $50 \mathrm{~km}$ from the state capital (Recife). This municipality is separated from the mainland by the Santa Cruz channel. The limits of the areas surveyed were: to the north by the 
Cunha, D. M. de A.; Cunha, A. G. da; Mota-Sobrinho, M. A. da; Danielski, L.; Calado, S. de C. Solid waste and contaminating agents on the northern coastal beaches of Pernambuco.

Catuama Bar (Goiana city), to the south by the Orange Bar (Igarassu city), to the west by the town of Itapissuma and east by the Atlantic Ocean (Leitão et al. 2007). The beaches north of Itamaracá (Sossego and Pontal da Ilha) receive terrigenous sediments from the Jaguaribe River, while the beaches south of Itamaracá (Forte Orange and São Paulo) receive sediment from the southern channel of the Santa Cruz Channel (at the Orange Bar) (ALMEIDA, MANSO 2011). The most urbananized beaches of Itamaracá (Pilar and Jaguaribe) receive no sediment input since no river flows near these beaches. The Itamaracá island beaches also feature carbonate in the sediment, coming from reefs found parallel to the beach line (Figure 2) (ALMEIDA, MANSO 2011). The terrigenous sediments are also distributed along the beaches by winds, that in Itamaracá island have two main directions throughout the year: one in the rainy season (March - August) with predominance of south-eastern wind; and other in the dry season (September - February) with predominance of northeast wind. In December, however, when the temperature is the warmest of the year, the winds are easterly (ALMEIDA, MANSO 2011). The beaches have low waves $(0.4 \mathrm{~m})$ characterizing the beaches of Itamaracá as dissipative (SUHAYDA et al., 1977) and the slope of the beaches is slightly accentuated.

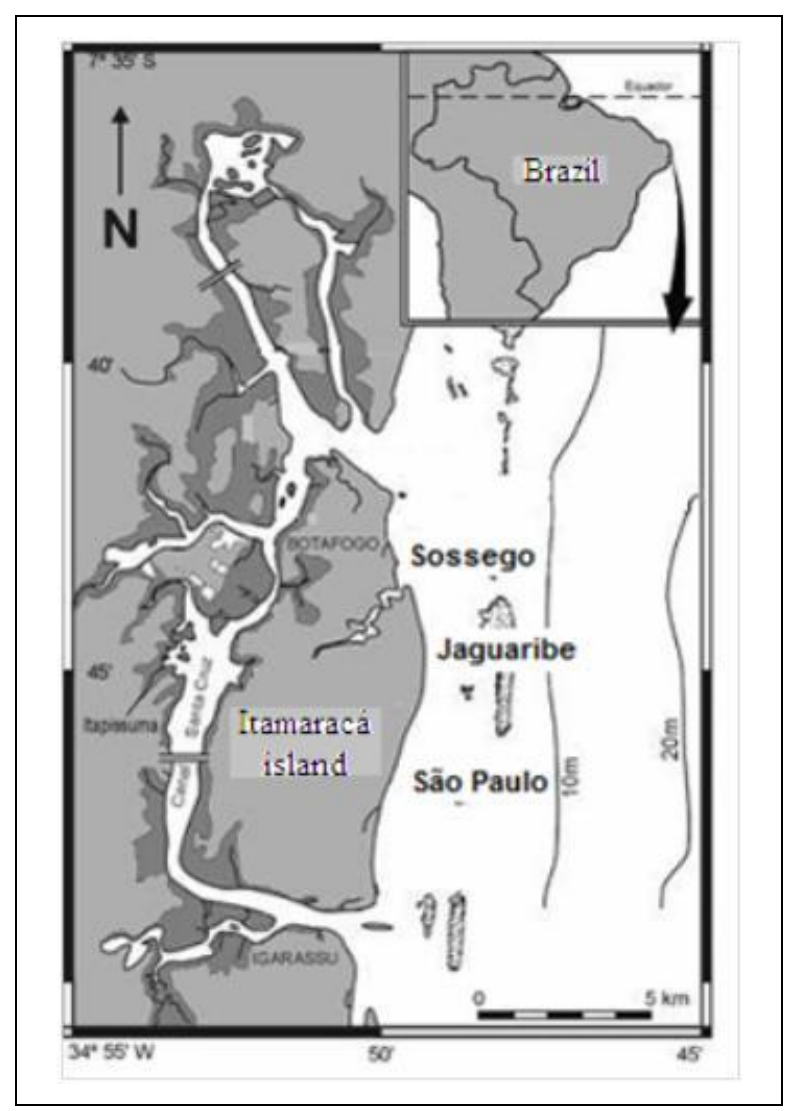

Figure 1 - Map of Itamaracá highlighting the studied beaches: Sossego; Jaguaribe and São Paulo, adapted from CUNHA et al. (2012).

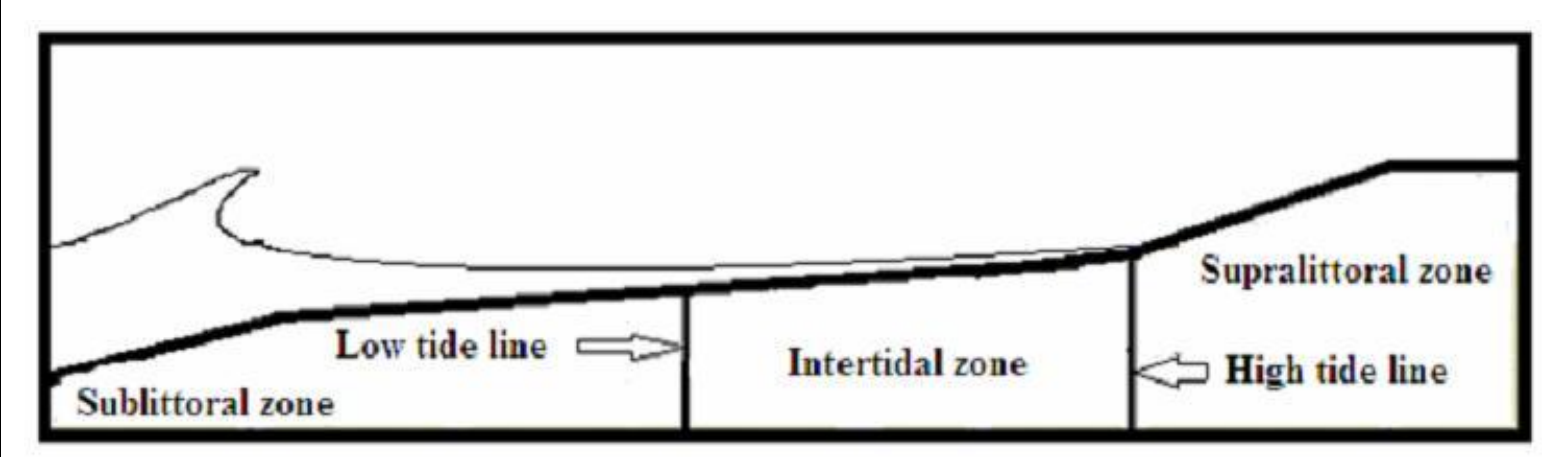

Figure 2 - Disposition of morphodynamic elements along a beach profile. 
Cunha, D. M. de A.; Cunha, A. G. da; Mota-Sobrinho, M. A. da; Danielski, L.; Calado, S. de C. Solid waste and contaminating agents on the northern coastal beaches of Pernambuco.

\section{MATERIAL AND METHODS}

The beaches Jaguaribe, São Paulo and Sossego were chosen for their distinct characteristics (Table 1).

Table 1 - Characteristics and factors anthropogenic used to separate of the areas studied, adapted DIAS-FILHO et al., 2011.

\begin{tabular}{|c|c|}
\hline Beach & Characteristic \\
\hline JAGUARIBE & $\begin{array}{l}\text { High commercial and tourist activity, with presence of hostels, } \\
\text { houses and bars, because of the high concentration of users } \\
\text { along the beach. }\end{array}$ \\
\hline SÃO PAULO & $\begin{array}{l}\text { Average commercial and tourist activity, with the presence of } \\
\text { houses and bars, and moderate concentration of users along the } \\
\text { beach. }\end{array}$ \\
\hline SOSSEGO & $\begin{array}{l}\text { Low business activity and tourism, with few houses and bars, } \\
\text { low concentration of users along the beach. }\end{array}$ \\
\hline
\end{tabular}

We adapted the methodology of PORTZ, MANZOLLI, SUL (2011) for field sampling. On three weekends in January and February, in the summer of 2013, the period with the highest concentration of people, samples of solid waste were taken from the three beaches mentioned above on Itamaracá island (Jaguaribe, São Paulo and Sossego).

On each beach, samples were taken from a total of $2250 \mathrm{~m}^{2}$ before the high tide line, and $1125 \mathrm{~m}^{2}$ after. The transects were demarcated with a manual GPS, demarcating the sampling fields so that the collections were always made in the same areas, corresponding to $25 \mathrm{~m}$ long and $10 \mathrm{~m}$ wide, with the high tide line at the center. The high tide line of the previous day was always used, a procedure that was repeated in all collections. The studies were held on weekends, with the Saturdays (26 January, 02 and 09 February) used for cleaning of the entire predetermined demarcated area (Figure 2).

The following day, starting from the marked point, we measured the length and width of each section, staked it out and cordoned it off with ropes until the collection was finished. Using gloves and $50 \mathrm{~L}$ biodegradable plastic bags, we collected all solid waste found in the sections for further screening, ignoring the solid waste of natural origin (leaf, twigs and mangrove plants, fish and fish pieces). After sorting, the items were classified according to source material (plastic, metal, wood, paper and glass) and possible pollution sources.

\section{RESULTS}

Solid wastes were divided into five categories (recreational on the beach, fishing, smoking, toiletries and not identified) according to the habits of the people who frequent the beachs. The category with the highest percentage of items, item as per meter respectively (Figure 4), was the activity we named recreation on the beach $(52.43 \%$ and 9.56$)$, followed by activity not identified (25.92\% and 4.45$)$, fishing (11.59\% and 1.72$)$, smoking $(9.06 \%$ and 1.70$)$ and toiletries $(1.16 \%$ and 0.17$)$. 
Cunha, D. M. de A.; Cunha, A. G. da; Mota-Sobrinho, M. A. da; Danielski, L.; Calado, S. de C. Solid waste and contaminating agents on the northern coastal beaches of Pernambuco.

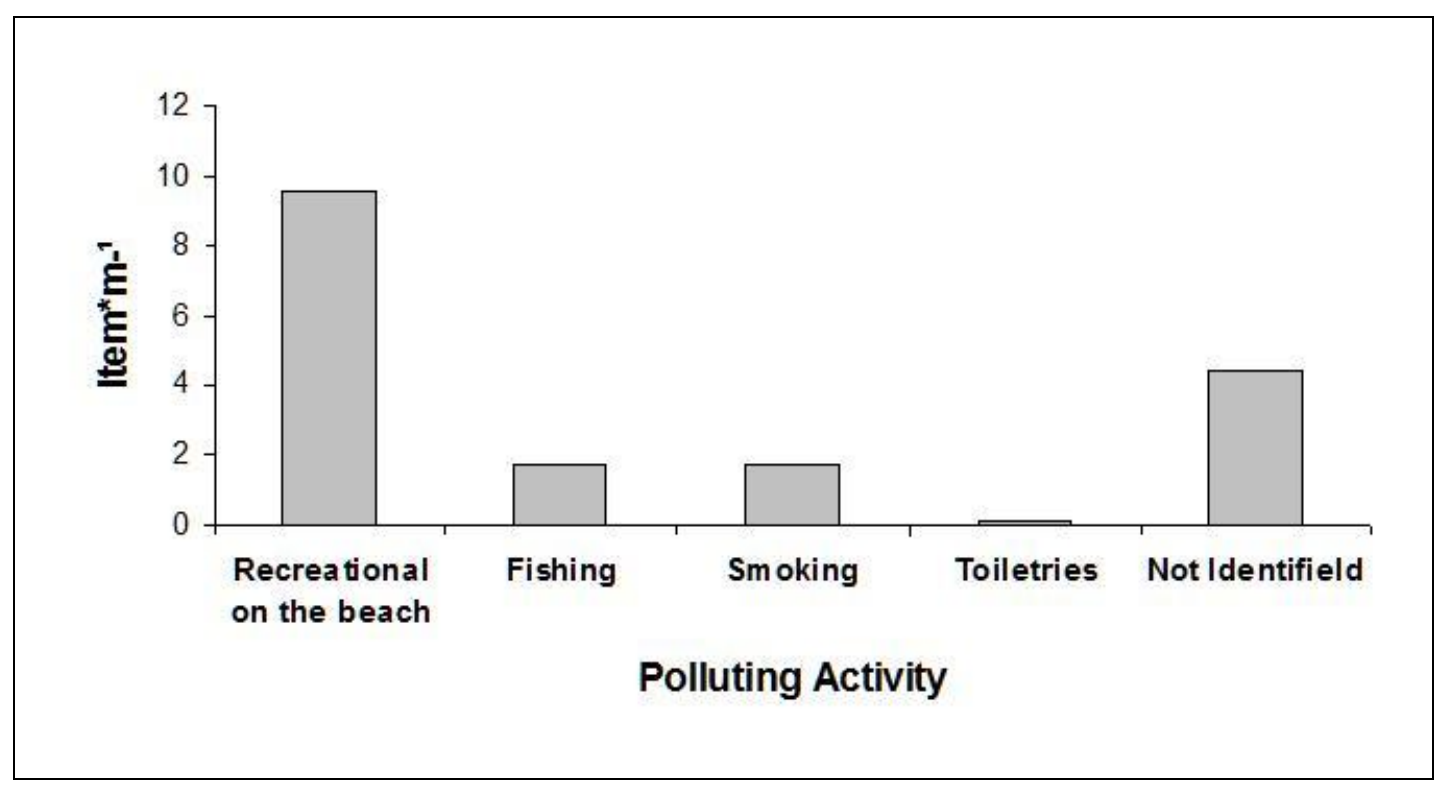

Figure 4 - Polluting activity, Number of items per meter (item*m-1), for all three studies on the beaches of Jaguaribe, São Paulo and Sossego.

Among the items found related to the recreational activities on the beach (Table 2 ), the greatest item was "Plastic cup" $(19.33 ; 32 ; 6.33)$ on the three beaches, followed by "Plastic packaging" $(20.67 ; 20.33 ; 5.33)$ and "Plastic bag" $(19 ; 20.33 ; 4.33)$. The items that had the lowest numbers were "Pen" $(0 ; 0 ; 0.33)$ and "Pot of sunscreen" $(0.33 ; 0 ; 0)$. All these solid wastes were from users who visited the supralittoral zone of the beach, at some point of the day, usually as a family, for a moment of leisure, concerned with their own comfort and not interested or unaware of proper care to dispose their waste in the very few suitable sites available.

Table 2 - Categories-Activity, number of items per meter per activity and their respective abundances and averages in the respective beaches sampled.

\begin{tabular}{|c|c|c|c|c|c|c|c|c|c|c|c|c|}
\hline \multirow[t]{2}{*}{ Categories-Activity/Beach } & \multicolumn{4}{|c|}{ Jaguaribe } & \multicolumn{4}{|c|}{ São Paulo } & \multicolumn{4}{|c|}{ Sossego } \\
\hline & col. 1 & col 2 & col. 3 & mean & col. 1 & col. 2 & col. 3 & mean & col. 1 & col. 2 & $\mathrm{col} 3$ & mean \\
\hline \multicolumn{13}{|l|}{ Recreation on the beach } \\
\hline Plastic packaging & 22 & 7 & 33 & 20.67 & 33 & 6 & 22 & 20.33 & 1 & 6 & 9 & 5.33 \\
\hline Yogurt container & 1 & 0 & 1 & 0.67 & 4 & 0 & 5 & 3.00 & 0 & 0 & 1 & 0.33 \\
\hline Plastic cup & 27 & 7 & 24 & 19.33 & 17 & 13 & 66 & 32.00 & 5 & 1 & 13 & 6.33 \\
\hline Straw & 19 & 5 & 15 & 13.00 & 9 & 1 & 15 & 8.33 & 1 & 1 & 7 & 3.00 \\
\hline Juice Box/ choc olate & 0 & 1 & 0 & 0.33 & 0 & 0 & 1 & 0.33 & 0 & 0 & 4 & 1.33 \\
\hline Disposable cutlery & 0 & 0 & 1 & 0.33 & 0 & 0 & 0 & 0.00 & 4 & 0 & 1 & 1.67 \\
\hline Beer can & 1 & 0 & 0 & 0.33 & 2 & 1 & 1 & 1.33 & 0 & 0 & 1 & 0.33 \\
\hline Popsicle stick & 5 & 3 & 3 & 3.67 & 18 & 2 & 7 & 9.00 & 2 & 5 & 0 & 2.33 \\
\hline Plastic plate & 0 & 0 & 0 & 0.00 & 0 & 0 & 10 & 3.33 & 1 & 0 & 1 & 0.67 \\
\hline Bag of popc orn / snack & 3 & 2 & 0 & 1.67 & 3 & 1 & 6 & 3.33 & 2 & 0 & 0 & 0.67 \\
\hline Lollipop stick & 1 & 0 & 1 & 0.67 & 4 & 0 & 5 & 3.00 & 0 & 0 & 0 & 0.00 \\
\hline Napkin & 2 & 0 & 0 & 0.67 & 0 & 0 & 3 & 1.00 & 0 & 0 & 0 & 0.00 \\
\hline Aluminum plates & 0 & 1 & 0 & 0.33 & 0 & 0 & 2 & 0.67 & 0 & 0 & 0 & 0.00 \\
\hline Bottle & 0 & 2 & 1 & 1.00 & 2 & 1 & 9 & 4.00 & 1 & 1 & 6 & 2.67 \\
\hline Plastic cover & 0 & 2 & 5 & 2.33 & 8 & 0 & 7 & 5.00 & 4 & 1 & 3 & 2.67 \\
\hline Toy & 0 & 2 & 1 & 1.00 & 4 & 0 & 7 & 3.67 & 0 & 0 & 0 & 0.00 \\
\hline Pen & 0 & 0 & 0 & 0.00 & 0 & 0 & 0 & 0.00 & 1 & 0 & 0 & 0.33 \\
\hline Hairclip & 0 & 1 & 1 & 0.67 & 0 & 0 & 0 & 0.00 & 0 & 0 & 0 & 0.00 \\
\hline Sunscreen bottle & 1 & 0 & 0 & 0.33 & 0 & 0 & 0 & 0.00 & 0 & 0 & 0 & 0.00 \\
\hline Peroxide Packaging & 1 & 0 & 1 & 0.67 & 0 & 0 & 0 & 0.00 & 0 & 0 & 0 & 0.00 \\
\hline Sandal & 1 & 0 & 0 & 0.33 & 1 & 0 & 3 & 1.33 & 0 & 0 & 0 & 0.00 \\
\hline Plastic bag & 24 & 11 & 22 & 19.00 & 21 & 10 & 30 & 20.33 & 4 & 5 & 4 & 4.33 \\
\hline
\end{tabular}


Cunha, D. M. de A.; Cunha, A. G. da; Mota-Sobrinho, M. A. da; Danielski, L.; Calado, S. de C. Solid waste and contaminating agents on the northern coastal beaches of Pernambuco.

Figure 5 shows that the distribution pattern of waste classified in the recreation on the beach category followed the same pattern as observed for the overall number of data items, especially on the beach of São Paulo which had the highest number of items collected pertaining to this activity. From this

Figure 5, it appears that the highest average value was obtained in the third collection on the beach of São Paulo (2.65 item* $\mathrm{m}^{-1}$ ) and the lowest mean value was obtained on the beach at Sossego beach in two of the collections $\left(0.27\right.$ item* $\left.\mathrm{m}^{-1}\right)$. It was also observed that the Sossego beach had the lowest mean value of waste compared to the other two beaches for all three collections made during this period.

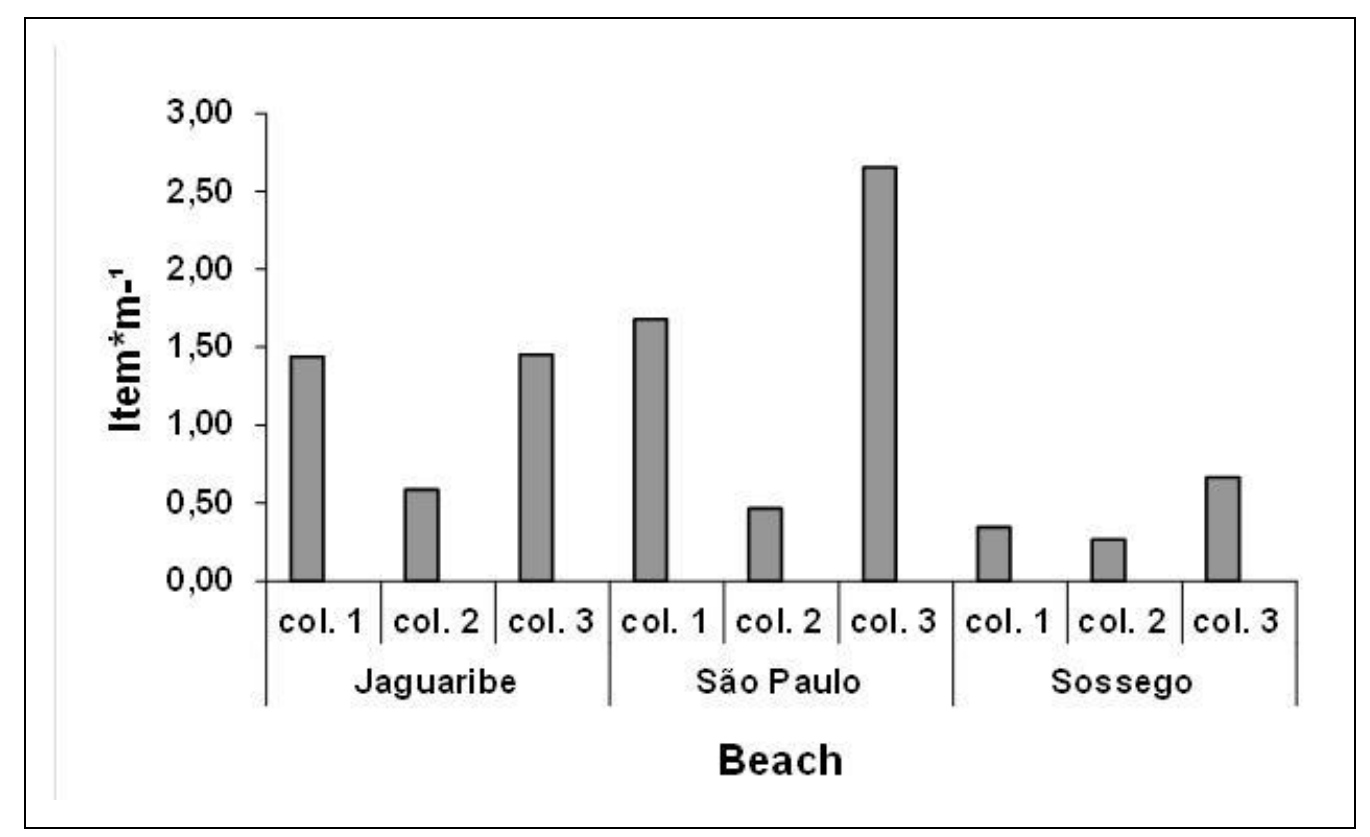

Figure 5 - Number of items per meter (items * m-1) for recreation on the beach, in the surveys conducted on the beaches of Jaguaribe, São Paulo and Sossego.

The other categories and their respective activities observed along the beaches sampled showed no representative number of items compared with data from recreational on the beach, except for the category of unidentified activities. Among the activities related (Table 3), the item that presented the highest mean was "plastic fragment" with 25.33 items obtained on beach São Paulo, followed by Styrofoam with 22.67 pieces found on the beach at Jaguaribe beach, both belonging to unidentified materials. Another item was found in abundance was cigarette butts, with 21 items found, pertaining to smoking, and "rope" with 18 fragments belonging to the fishing activity, found on the beach at Jaguaribe (Table 3 ). 
Cunha, D. M. de A.; Cunha, A. G. da; Mota-Sobrinho, M. A. da; Danielski, L.; Calado, S. de C. Solid waste and contaminating agents on the northern coastal beaches of Pernambuco.

Table 3 - Categories-Activity, number of items per meter per activity and their respective numbers and averages for each beach.

\begin{tabular}{|c|c|c|c|c|c|c|c|c|c|c|c|c|}
\hline \multirow[t]{2}{*}{ Categories-Activity/Beach } & \multicolumn{4}{|c|}{ Jaguaribe } & \multicolumn{4}{|c|}{ São Paulo } & \multicolumn{4}{|c|}{ Sossego } \\
\hline & col. 1 & col. 2 & $\mathrm{col} .3$ & mean & col. 1 & $\mathrm{col} .2$ & $\mathrm{col} .3$ & mean & col. 1 & col. 2 & $\mathrm{col} .3$ & mean \\
\hline \multicolumn{13}{|l|}{ Fishing } \\
\hline rope & 18 & 24 & 12 & 18.00 & 23 & 4 & 3 & 10.00 & 23 & 3 & 6 & 10.67 \\
\hline Fishing Line & 3 & 0 & 1 & 1.33 & 2 & 0 & 3 & 1.67 & 0 & 3 & 0 & 1.00 \\
\hline Fishing net & 0 & 0 & 1 & 0.33 & 0 & 0 & 0 & 0.00 & 0 & 0 & 0 & 0.00 \\
\hline \multicolumn{13}{|l|}{ Smoking } \\
\hline Match stick & 0 & 0 & 0 & 0.00 & 5 & 0 & 1 & 2.00 & 0 & 1 & 0 & 0.33 \\
\hline cigarette butt & 19 & 12 & 32 & 21.00 & 20 & 3 & 23 & 15.33 & 2 & 1 & 9 & 4.00 \\
\hline \multicolumn{13}{|l|}{ Toiletries } \\
\hline swab & 1 & 0 & 0 & 0.33 & 0 & 0 & 4 & 1.33 & 1 & 0 & 0 & 0.33 \\
\hline Band-aid & 0 & 0 & 0 & 0.00 & 1 & 0 & 0 & 0.33 & 0 & 0 & 0 & 0.00 \\
\hline female absorbent napkin & 0 & 1 & 0 & 0.33 & 0 & 0 & 0 & 0.00 & 0 & 0 & 0 & 0.00 \\
\hline cosmetic & 0 & 0 & 0 & 0.00 & 0 & 0 & 1 & 0.33 & 0 & 1 & 1 & 0.67 \\
\hline Dis posable baby diaper & 0 & 0 & 0 & 0.00 & 0 & 0 & 1 & 0.33 & 0 & 0 & 1 & 0.33 \\
\hline \multicolumn{13}{|l|}{ Not identifield } \\
\hline rubber & 1 & 0 & 0 & 0.33 & 2 & 0 & 3 & 1.67 & 0 & 0 & 0 & 0.00 \\
\hline anthropogenic wood & 1 & 0 & 0 & 0.33 & 7 & 2 & 0 & 3.00 & 1 & 4 & 1 & 2.00 \\
\hline synthetic foam & 0 & 0 & 1 & 0.33 & 0 & 0 & 0 & 0.00 & 0 & 1 & 0 & 0.33 \\
\hline Styrofoam & 8 & 4 & 56 & 22.67 & 17 & 3 & 28 & 16.00 & 4 & 2 & 2 & 2.67 \\
\hline Scrap of paper & 1 & 2 & 0 & 1.00 & 1 & 1 & 3 & 1.67 & 0 & 0 & 3 & 1.00 \\
\hline Fragment of plastic & 13 & 18 & 15 & 15.33 & 27 & 9 & 40 & 25.33 & 21 & 5 & 9 & 11.67 \\
\hline tape & 3 & 6 & 3 & 4.00 & 1 & 0 & 0 & 0.33 & 0 & 3 & 2 & 1.67 \\
\hline
\end{tabular}

The collection that had the highest average number of items per meter on the sampled beaches was the third at Jaguaribe beach with 0.40 item* $\mathrm{m}^{-1}$, followed by the the third collection at the São Paulo beach with 0.37 item*m-1 and first collection with 0.35 item*m-1 on the Sossego beach (Figure 6).

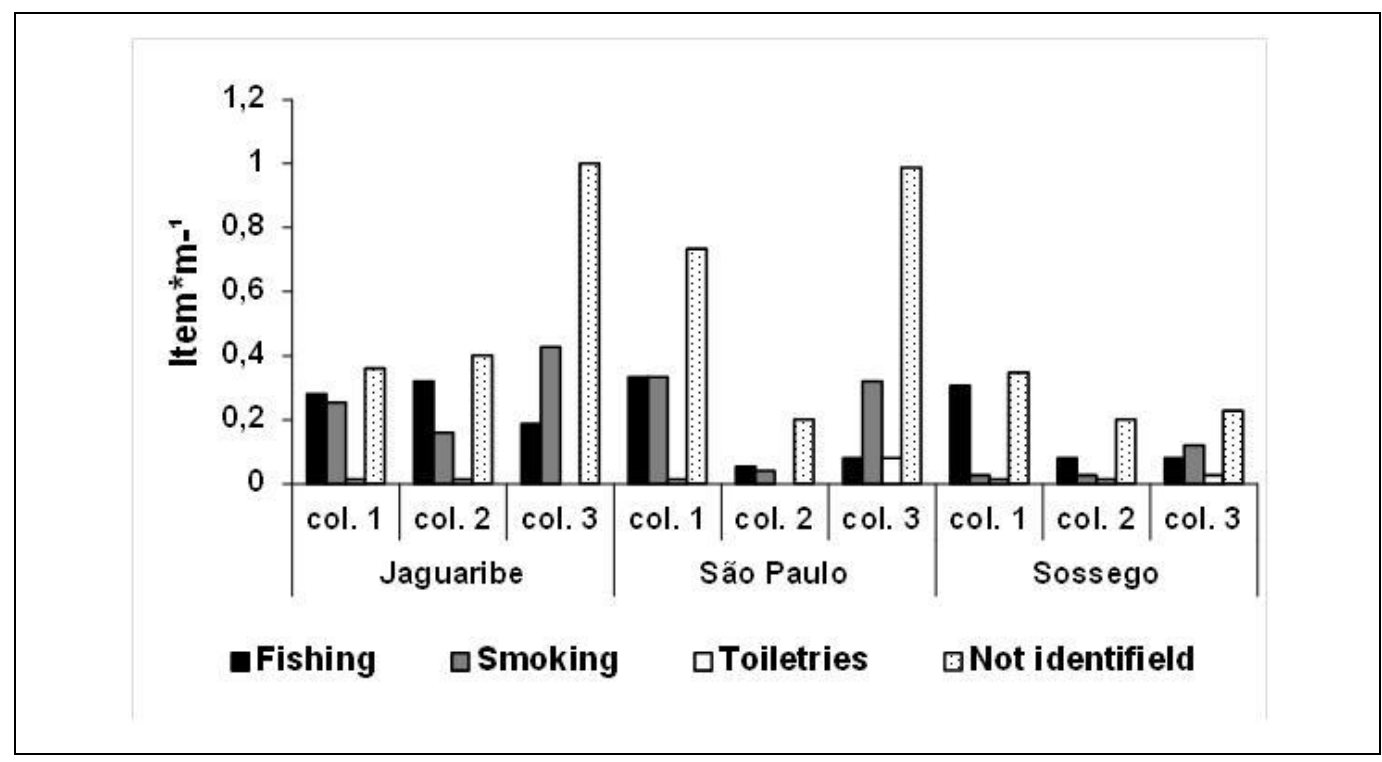

Figure 6 - The number of item*m-1 per beach found in the collections conducted on the beaches Jaguaribe, São Paulo and Sossego.

\section{DISCUSSION}

This study revealed a worrying situation concerning the northern coast of Pernambuco. This is evident from the small size of most of the pieces of solid waste discarded by many users, consciously or unconsciously, and who who were not concerned about disposing of their waste properly, making it difficult to clean the area. This behavior can be seen on all the beaches 
Cunha, D. M. de A.; Cunha, A. G. da; Mota-Sobrinho, M. A. da; Danielski, L.; Calado, S. de C. Solid waste and contaminating agents on the northern coastal beaches of Pernambuco.

along the northeast coast, and probably the whole of the Brazilian coast. Given that, the local authorities do not clean every beach, only those most visited by tourists. This poses a risk to beach visitors. For example, we found glass and metal remains, which can cause small and medium injuries. Moreover, we found materials that can convey hazardous and infectious diseases (AIDS, hepatitis, etc.) for example, personal hygiene materials found loose along the beaches studied.

Among the most representative materials, cigarette butts were classified within the plastic category SOARES et al. (2007). The highest percentage was up to $10 \%$ of the waste collected, which was also found by CALDAS (2007). This item can contribute significantly to increasing the level of contamination of beaches, on days with a high concentration of people. In addition, this item can be easily carried by the wind and camouflaged in the sand, making manual pickup difficult and accumulating in the sand, over the years.

A very common item on the beaches are aluminum cans, serving as containers for beverages that are widely appreciated in this type of environment and leisure time. Despite this, as can be seen in Table 3, few cans were found. This is because the market for aluminum recycling in Brazil is one of the largest in the world (SCARLATO, PONTIN 1992), carried out efficiently by autonomous collectors. According to the State Plan for Solid Waste Pernambuco, Itamaracá Island has 65 collectors, enough to collect most of the improperly disposed used cans.

The largest number of items was observed in the third collection from the three beaches studied, a result of a higher number of people using these beaches, as well as all the other beaches of the municipality since the collection coincided with the carnival season when the number of people using the beaches of Itamaracá Island increases, which corresponds to the increase of solid waste found on these beaches. Another aggravating factor in the increase of solid waste on the beaches, also observed by OLIVEIRA (2008), is the activity related to recreational fishing, which increases on weekends, thereby contributing to a greater accumulation of waste along the waterfront, not to mention the risk to visitors, since rusty fishhooks can contaminate people with dangerous diseases like tetanus. Furthermore, lines, nets and plastic bags used by weekend fishermen take a long time to degrade in the environment. This material may arrest, maim, intoxicate and kill the wildlife live in these environments, given that among the leisure activities observed along the waterfront, amateur sport fishing is still widely practiced.

\section{CONCLUSION}

The study showed that the amount of solid waste is directly linked to the number of users on the beaches of Itamaracá Island. In the period when there were more people (Carnival time), there was an increase in number of items collected from the sampled beaches. The major sources of waste identified from the three presented the following sequence: beach recreational activities, then unidentified activities, followed by fishing, smoking and toiletries. This shows that users do not care for their own recreation areas on weekends, and more problematical, can acquire infectious disease. The results show the need for emergency measures, preventative actions, planned between government and society, with the purpose of reducing the inappropriate disposal of solid waste on beaches. This can be done by collecting garbage along the entire coast of Itamaracá Island, especially before the weekends, adjusted according to the need of the locality, and the placement of bins along the coast and proper disposal of solid waste amenable for recycling. Finally, continuing environmental education programs need to be established, together with society, to increase awareness of responsibility for the generation of waste, as has been done for the urban beaches of the state capital.

\section{REFERENCES}

ADMIRALTY AND LAW GUIDE, 2013.

http://www.admiraltylawguide.com/conven/unclostable.html\#pre,

ALMEIDA, T. L. de M.; MANSO, V. do A. V. SEDIMENTOLOGIA DA PLATAFORMA INTERNA

ADJACENTE A ILHA DE ITAMARACÁ - PE. Estudos Geológicos, v. 21 (1), 2011. 
Cunha, D. M. de A.; Cunha, A. G. da; Mota-Sobrinho, M. A. da; Danielski, L.; Calado, S. de C. Solid waste and contaminating agents on the northern coastal beaches of Pernambuco.

ANTIA, E. E. 1993. A morphodynamic model of sandy beach susceptibility to tar pollution and shelf cleansing on the Nigerian Coast. Journal of Coastal Research v. 9, 1065-1074.

ARAÚJO, M. C. B, COSTA, M. Lixo no ambiente marinho. Ciência Hoje: Rio de Janeiro, vol. 32, n. 191, p.64-67, 2003.

BRUNO, G. S.; SANTOS, J. L. ANÁLISE QUALITATIVA DOS DETRITOS ACUMULADOS NA PRAIA DO CUIÚBA, GUARUJÁ, SP. Revista Ceciliana, v. 3, p. 44-48, 2011.

CALDAS, A. H. M. Análise da disposição de resíduos sólidos e da percepção dos usuários em áreas costeiras: um potencial de degradação ambiental. 2007. 60f. Monografia (Especialização em Gerenciamento e Tecnologias Ambientais) - Escola Politécnica, Universidade Federal da Bahia, Salvador. 2007.

CARVALHO-SOUZA, G. F.; TINÔCO, M. S. Avaliação do lixo marinho em costões rochosos na Baía de Todos os Santos, Bahia, Brasil. Revista da Gestão Costeira Integrada, v. 11, n. 1, p. 135-143, 2011.

CLAEREBOUDT, M. R. (2004). Shore litter along sandy beaches of the Gulf of Oman. Marine Pollution Bulletin 49, 770-777.

CUNHA, A. G.; SCHWAMBORN, R.; SANTOS, T. G. dos. Influência espacial, luminosa e lunar sobre a população de Lucifer faxoni (Borradaile 1915) no sistema estuarino do Canal de Santa Cruz, Pernambuco, Brasil. Tropical Oceanography, v. 40, n. 2, p. 285-294, 2012.

DEMAJOROVIC, J. A evolução dos modelos de gestão de resíduos sólidos e seus instrumentos. Cadernos Fundap, São Paulo, v. 20, p. 47-58, 1996.

DIAS FILHO, M.; SILVA-CAVALCANTI, J. S.; ARAÚJO, M. C. B.; SILVA, A. C. M. Avaliação da Percepção Pública na Contaminação por Lixo Marinho de acordo com o Perfil do Usuário: Estudo de Caso em uma Praia Urbana no Nordeste do Brasil. Revista da Gestão Costeira Integrada 11(1):49-55 (2011).

DIXON, T.J.; DIXON, T.R. 1983. Marine litter distribution and composition in the North Sea. Marine Pollution Bulletin 14, 145-148.

LEITÃO, S. S.; BARBOSA, J. M.; CARRARO, F. G. P. Caracterização dos impactos ambientais na Ilha de Itamaracá, PE. Revista Brasileira Engenharia de Pesca 2. p. 101-111. Maio/2007.

MARTINS, E. M. O. Direito marítimo internacional: da responsabilidade internacional pelos danos causados ao meio ambiente marinho. Verba Juris ano 7, n. 7, jan./dez. 2008.

MASCARENHAS, R.; BATISTA, C.; MOURA, I. F. M. S.; CALDAS, A. R.; COSTA NETO, J. M.; SOUZA, M. Q. V.; ROSA, S. S.; BARROS, T. V. S. Lixo marinho em área de reprodução de tartarugas marinhas no Estado da Paraíba (Nordeste do Brasil). Gerenciamento Costeiro Integrado, v. 8, p. 221-231, 2008.

NEVES, R.C.; SANTOS, L. A. S.; OLIVEIRA, K. S. S.; NOGUEIRA, I. C. M.; LOUREIRO, D. V.; FRANCO, T.; FARIAS, P. M.; BOURGUINON, S. N.; CATABRIGA, G. M.; BONI, G. C.; QUARESMA, V. S. Análise qualitativa da distribuição do lixo na praia da Barrinha (Vila Velha-ES). Revista da Gestão Costeira Integrada, v. 11, n. 1, p. 57-64, 2011.

OLIVEIRA, A. L. Resíduos sólidos e processos sedimentares na praia de Massaguaçú, Caraguatatuba - São Paulo. Novembro/2008. 50f. Monografia (Bacharelado em Oceanografia) - Instituto Oceanográfico, Universidade de São Paulo, São Paulo. 2008.

OLIVEIRA, A. L.; TESSLER, M. G.; TURRA, A. Distribuição de lixo ao longo de praias arenosas Estudo de caso na Praia de Massaguaçu, Caraguatatuba, SP. Revista de Gestão Costeira Integrada, v. 11, p. 75-84, 2011.

PORTZ, L.; MANZOLLI, R. P.; SUL, J. A. I. do. Marine debris on Rio Grande do Sul north coast, Brazil: spatial and temporal patterns. Revista da Gestão Costeira Integrada Journal of Integrated Coastal Zone Management. 11(1): 41-48 (2011).

SANTANA NETO, S. P. de; SILVA, I. R.; CERQUEIRA, M. B.; TINOCO, M. S. Perfil sócioeconômico de usuários de praia e percepção sobre a poluição por lixo marinho: Praia do Porto 
Cunha, D. M. de A.; Cunha, A. G. da; Mota-Sobrinho, M. A. da; Danielski, L.; Calado, S. de C. Solid waste and contaminating agents on the northern coastal beaches of Pernambuco.

da Barra, BA, Brasil. Revista de Gestão Costeira Integrada / Journal of Integrated Coastal Zone Management 11(2):197-206 (2011).

SANTOS, I. R.; FRIEDRICH, A. C.; FILMANN, G.; WALLNER-KERSANACH, M.; COSTA, V, R. Geração de resíduos sólidos pelos usuários da Praia do Cassino, RS, Brasil. Gerenciamento Costeiro Integrado, Itajaí -SC, v. 3, p. 12-14, 2004.

SANTOS, I. R.; Tubaroes de Coleira. Ciencia Hoje, p. 54 - 55, 2006.

SCARLATO, F. C.; PONTIN, J. A. Do nicho ao lixo - ambiente, sociedade e educação. 13a. ed. São Paulo: Atual Editora, 1992. Série Meio Ambiente. (p. 57 a 60).

SOARES, A. M. Contaminação da linha-do-deixa da praia da Boa Viagem (Recife-PE) por resíduos sólidos no verão de 2005: uma nova metodologia de avaliação. XII Congresso Latino-Americano De Ciências Do Mar - Colacmar. Florianópolis (SC/Brasil), 15 a 19 de abril de 2007.

SUHAYDA, J. N.; HSU, S. A. ; ROBERTS, H. H.; SHORT, A. D. Documentation and analisys of coastal processes northeast coast of Brasil. Louisiana State University. Technical report. N. 238. 98p. 1977;

REES, G.; POND, K. (1995). Marine litter monitoring programs - a review of methods with special reference to national surveys. Marine Pollution Bulletin 30, 103-108.

RIBIC, C.A., DIXON, T.R.; VINING, I. 1992. Marine Debris Survey Manual. In, pp.92 NOAA Technical Report NMFS 108. 